\title{
LOOKING BEHIND THE LETTER OF THE LAW
}

JOHN H. WIGMORE*

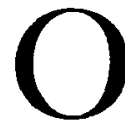

UR learned and genial friend, in whose honor we affectionately offer this tribute, was particularly gifted with the tendency to go behind the mere letter of the rule, or its abstract or logical formulation, and to consider how it operated in practice.

This attitude towards the rules of law-an attitude that imports an understanding of the fullest significance of those rules-is particularly necessary in judging the records of legal systems alien to our own. The purport of the records may be verbally plain, and the ideas which the words convey may be familiar and apparently obvious, but a search into the background may reveal something very different. The rules or principles may turn out to mean something very different; or they may turn out to be-no rules at all in the sense of accepted and effective practices in the administration of justice.

It occurs to me that I shall be offering something germane to that wise attitude of our learned comrade if $I$ here call attention to some examples which I have met in scanning the records of foreign laws.

\section{$\mathrm{I}$}

The latter kind of revelation above mentioned is found in those bodies of legal records which have all the marks of actual law, and yet were probably never in force at all. I refer here to the formal records of Irish-Celtic law and of Brahman-Hindu law. There are several volumes extant of the former class and scores of volumes of the latter class. The Irish laws purport to represent concrete rules, laid down for detailed cases by the Brehons, or judges. The Brahman laws purport also to represent elaborate rules for concrete cases (but sometimes formulated like a code) laid down by the pundits, or priestly advisers, of the rajahs. And yet it is now clear (and I think generally accepted) that the greater part of them were never in force as law. They were mainly the personal views of chambered jurists, elaborating logically the consequences of their theoretical imaginations. In the Irish books this conclusion may be inferred almost from the mere perusal of the texts, so fantastically scholastic are some of these lucubrations; but as no modern experience exists as to their attempted enforce-

* Dean Emeritus, Northwestern University Law School. 
ment, no practical test of this conclusion is attainable. But the Brahman books, which to some extent have the same unreal purport, were put into application by the British judges when the judicial system in India was organized (nearly a century and a half ago), and there arose ample opportunity to test the validity of the pundits' rules (property, inheritance, etc.) in the community. Some fifty years ago a great controversy arose and raged over their validity. The result was a shaking of faith all along the line. However, as by that time the pundits' rules applied by the British judges had largely become settled law, it was too late to repudiate their authority. There remained a caution in depending upon them.

\section{II}

But it is of the other kind of unreality in apparent rules that I wish more particularly to speak, because the instances are more odd and even entertaining, and because the ones that I shall offer lie in the very field in which our learned friend was so adept, the law of evidence. I refer to that "unreality" which consists in a rule seeming (to us) to be absurd or cruel or perversely illogical until we go behind the curtain of the law and perceive the social circumstances amid which it grew up.

Let the first instance be taken from the practice of torture of witnesses. This practice was abolished in England, Scotland and the Colonies two and a half centuries ago, not merely because of its cruelty but because of its supposed futility. Chief Baron Gilbert wrote, in the early I700's: "Pain and force may compel men to confess what is not the truth of facts, and consequently such extorted confessions are not to be depended on." And of course that is the accepted modern Occidental view of human nature; violence is a sure way to block the revelation of truth because it tends to elicit false testimony.

But in parts of the Orient the opposite principle of human nature obtains. There are (or have been) countries in which violence to witnesses is the only sure way to get at the truth. The following chronicle illustrates this (it is from an American observer who lived in the I89o's at the Court of Korea as personal adviser to the Emperor):

Torture had been abolished by law, it is true, but it was too deeply part of native custom to root out easily. The practice is so widespread in the Far East that the French were obliged to admit it into their colonial legal code, though in a mild form, to be sure. They found out that in their war on river pirates, they could not find witnesses and could not expect to, for it was certain death for a villager to tell on his neighbor. Confession by a witness under torture was admitted, however, in village custom. If a witness returning from court could show marks of torture on his body, he was safe. The French, therefore, paddled every witness thoroughly in a piracy case, 
with the full consent of the paddled, before ever a question was asked of him. They beat him with an instrument rather like a canoe paddle or a thin cricket bat, on a part where he could not be injured, but where bruises would show up beautifully. After that he could tell the truth, if he were capable of that, without fear of death from his fellow villagers. The bruises had to show, though, when he got home.

Koreans practiced that minor form of torture also, sometimes on witnesses and sometimes as a punishment for light offenses. .... [But justice was now reformed, and torture had been abolished.] The sequel to the war was the trial of the rebel leaders at Seoul. I wished it to be an exemplary trial. It should be the first illustration of the new order of justice in Korea. Beyond presenting a report to the Emperor of the reasons of the revolt, what had happened and the circumstances under which the accused were presented for trial, I intended to have no part in it, except to sit as an observer with the Korean judges and to see to it that the men had a proper defense and that witnesses were admitted in their favor as well as against them. . . . But I was disappointed in the efficiency of our new model of justice. Seeing that I did not intend to try them myself, and would not testify, though $I$ knew their cases, so as to give them every possible chance, accused and witnesses looked me blandly in the eye and lied brazenly. Finally the chief justice turned to me and said that though he hated to disrupt the course of Western justice, he felt that an ever so slight return to primitive methods might give better results, and asked if he might threaten to use the paddle. It seemed to me that, if he threatened, it might show the prisoners that they had better not force the issue, and I consented to his ordering the paddles brought out, if he promised to accept defeat if they called his bluff, in which case I would agree to testify. The court servants brought out a kind of sawbuck, over which the victim was to be held while being spanked, and the paddles. The effect was instantaneous. They all clamored to be readmitted to examination, as they had remembered something. The instruments were removed and the trial finished in an orderly manner. But it was the last trial on the Western model, as well as the first. ${ }^{2}$

Oddly enough, this paradoxical use of compulsion to get a willing witness had a near counterpart in the history of our own law. Professor Thayer pointed it out a long time ago. A notable statute of Elizabeth imposed a penalty on a person who failed to appear when summoned as a witness. ${ }^{2}$ On its face it is a measure to compel the recalcitrant; but in the background of the times was the stern law against maintenance, i.e., meddling as a partisan in another person's litigation; and potential witnesses were loath to come. "If he had come to the Bar out of his own head and spoken for one or the other," said a judge a century before, "it is maintenance, and he will be punished for it." And in chancery, at the same period, a petition for a subpoena says "The same David will gladly acknowledge the truth of the same matters, but he would have a commandment from you, for the cause that he should not be holden partial in the matter." Thus, in our own past also, a rule apparently meant to

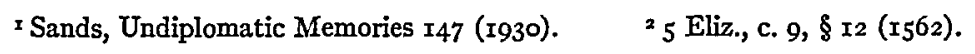


force truth from the unwilling was really meant to make it easy for the willing.

Let us take a second instance from Oriental justice, this time from modern Africa. Ideal justice in the Orient is prompt, and prompt action in justice is more often the fact, in the simpler communities at least. The tedious futility of the careful Occidental procedure is to them repugnant. And this is the anecdote told by the Earl of Cromer, long a denizen of Egypt:

When the French criminal code was put into force in parts of Egypt, one of the principal Algerian Sheikhs exclaimed: "Then there will be no justice! Witnesses will be required!' The Sheikh was not in the least struck with the fact that in the absence of witnesses an innocent man might possibly be condemned. What struck him was that, as no one could be condemned without witnesses, guilty people would generally escape punishment. This is precisely what was happening in Egypt [since the western criminal courts were introduced].3

Here, then, is the paradox that a procedure not requiring witnesses is deemed to get at the truth better than a procedure requiring them.

A third instance $I$ offer from our own law. It concerns the time-honored common-law rule disqualifying a civil party from testifying in his own case. However natural that rule may once have seemed, its anomaly has been felt for nearly a century (since the Common Law Practice Commissioners in 1853 recommended its abolition, on grounds of "plain sense and reason"). To forbid a party to testify who wishes to tell his story seems to us to be contrary to "plain sense and reason." But, on looking behind this obviousness of the modern rule, we may find social circumstances that make it anomalous. Chief Justice Bleckley once announced that "it is becoming, and to be commended, in a party, not to testify, if he can avoid it without positive injury to the cause of truth and justice." 4 When I first read (and quoted) this opinion, I explained it on the theory that in the old-time Southern communities the sentiment of personal honor made it repugnant to a sensitive gentleman to place himself in a situation where his word may be doubted by his fellows and flouted by their verdict. This was indeed a new aspect of the rule to me. But still more light was thrown for me on the rule when one day in $I 898$, at the Saratoga meeting of the American Bar Association, I met Mr. N. J. Hammond, an accomplished and thoughtful member of the Georgia bar and at one time attorney-general of that state. In one of those extra-curricular evening meetings, around a table full of glasses in the old Grand Union Hotel,

${ }_{2} 2$ Cromer, Modern Egypt 552 (1908).

4 Thompson v. Daville, 59 Ga. 472,480 (1877). 
where experiences were swapped between lawyers of all regions, he affirmed to me that in his judgment the abolition of parties' incompetency had been a mistake; and he illustrated his view with this anecdote: One day in court, shortly after the new qualifying statute had passed, he was sitting with a client awaiting the course of the docket, when the client pulled his sleeve and pointed to the witness-stand, where one of the parties in the case was about to testify. "How can that be allowed?" asked the client. "That is the new law," replied Mr. Hammond, "parties may now testify." "That is shocking," protested the astonished client, "If that is the law, the time may come when a gentleman will have to take the stand and lie to support his owe casel"

Here again is an instance of an apparently simple and rational rule becoming shocking when considered in the light of local sentiments and social habits.

And finally, another instance in our own law, viewed from the point of view of a foreign lawyer. For generations past our courts have been repeating, as a limitation on the use of expert testimony, this principle: ". . . . a witness cannot be allowed to express an opinion upon the exact question which the jury are required to decide." 5 The result is that when an expert insurance adjuster is asked to state whether the storage of gasoline in a dwelling house increases the insurer's risk; or when an expert carpenter is asked to state whether a certain stairway was safely built; or when an engineer is asked to state whether a certain train could have been stopped within 600 feet; or when an expert surveyor is asked to state whether the boundaries described in a deed are the very boundaries of the land in dispute; or when a medical man is asked to state whether by a certain injury the victim was permanently disabled; or when a qualified person is asked to state whether another was solvent or was an agent or had paid a note or had finished a job in a reasonable time, and so on ad infinitum, hundreds of rulings forbid that testimony to be given.

So now comes the foreign lawyer, and asks his friend, "What was the reason for prohibiting that testimony?" And the friend replies, "Because that is the very question which the jury is to decide." Whereon the foreign lawyer replies, in astonishment, "But that would seem to be the very reason for its admission. Instruction from qualified persons is what the jury want, is it not? ${ }^{6}$ Why call qualified persons, if not to help the jury on the very point in issue?"

5 One of the many cases to this effect is Yost v. Conroy, 92 Ind. 464, 47I (I883).

${ }^{6}$ See the opinion of Danforth, J., in Snow v. Boston R. Co., 65 Me. 230 (r875). 
"No," answers the American friend, "our law forbids that; the jury might believe them, and thus might go wrong."

"But if these experts were wrong, then experts could be called on the other side to say so?"

"Yes, of course; but then the jury would be confused."

"They might; but may they not also be confused when any other witnesses on opposite sides contradict each other?"

"Yes, but that can't be helped."

"Then why call the experts at all?"

"No, we couldn't very well do that, but we can call them and then stop them from being of any service; which is what our rule amounts to."

Once, long ago, in Scotland, an English lawyer attending a trial noticed that the judge forbade counsel to put leading questions on cross-examination. "Not ask leading questions on cross-examination?" exclaimed he, "my God, what a country!"

I sometimes think that a candid lawyer from any other civilized country would give expression to like astonishment on hearing of the vagaries of our opinion rule.

It goes to illustrate my theme, that a rule of law in any country cannot be fully comprehended, in its apparent irrationality, without knowing something of the circumstances under which it has grown up and is practiced. 